\title{
FABRICATION AND EVALUATION EXTRACTION UNIT FOR GINNING EGYPTIAN COTTON
}

\author{
Abd El-Hameed,Sh.*， A.E. Elyamani* and S. E. Bader*
}

\section{ABSTRACT}

This research aims to develop and evaluate small prototype machine performance during gin Egyptian cotton in laboratory. This machine helped technicians scholars to study the effect of ginning experimental parameters on fiber cotton quality properties. The independent variables in this study were: four rotation speeds were $0.79 \mathrm{~m} / \mathrm{s}$ (60 r.p.m) ,1.18 $\mathrm{m} / \mathrm{s}$ (90 r.p.m), $1.60 \mathrm{~m} / \mathrm{s}(120$ r.p.m), and $2.36 \mathrm{~m} / \mathrm{s}(180$ r.p.m), three feeding rates were $30 \mathrm{~kg} / \mathrm{h}, 45 \mathrm{~kg} / \mathrm{h}$ and $60 \mathrm{~kg} / \mathrm{h}$ and three values of clearance between two drums of 3,4 and $5 \mathrm{~mm}$. Evaluation parameters were : gin stand productivity, lint turn out, seed wastage mass, gin lint losses and ginning efficiency. Also, energy requirement and total cost production were determined. On other hand, a comparative study between development prototype gin machine and the conventional McCarthy gin roller made to evaluate fiber properties. The test results for developed gin stand performance found that, a maximum of ginning efficiency, gin stand capacity, lint turn out percentage were $81.28 \%$. $32.8 \mathrm{~kg}$, and $43.1 \%$, respectively . also, maximum of seeds wastage mass was $17.49 \mathrm{~kg} / \mathrm{h}$. while, minimum of gin lint losses percentage was $3.5 \%$ and minimum of energy requirement was $154.26 \mathrm{~kW} . \mathrm{h} / \mathrm{Mg}$. On other hand, minimum of total operation cost was $231.40 \mathrm{L.E} / \mathrm{Mg}$ while, minimum of criterion function cost was $364.10 \mathrm{~L} . \mathrm{E} / \mathrm{Mg}$. consequently, the new developed prototype machine was influenced by all of independent variables. Recently, a comparative study between the developed gin stand and the conventional McCarthy gin roller on the fiber quality properties found that the gin stand developed was consider the best for ginning Egyptian seed cotton samples.

Key Words: Developed machine, gin, seeds, fibers.

*Agric. Eng. Res. Institute,Agric. Res. Center, Dokki, Giza, Egypt 


\section{INTRODUCTION}

otton is the most important fiber crop in the world as well as in Egypt. But this plant are exposed to many pests so, the country spend millions of pounds to increase the production by helping the technicians to control the pests. These pests can annihilate all crops if it is not controlled in other hand keep on good quality for fibers and seeds. Anthony (1979) determined the effects of individual processing machines and combinations on lint quality, and their electricity consumption of the 14 machine combinations investigated, the treatment that included, 2 tower driers, a cylinder cleaner, stick machine, impact cleaner, gin stand and 2 stages of lint cleaning produced highest classer's grade classification, the lowest trash content and lint turn out from both the high and low moisture content seed cotton samples. Treatments which included only the gin stand and one lint cleaner produced classer's grades among the highest and lint trash contents among the lowest. Lint turn outs for these treatments ranked in the intermediate range. About 55 - $60 \%$ of the total energy required by max. machine processing was consumed by the fans and separators. The lower moisture cotton consumed 20 - 40\% more electric energy $/ \mathrm{kg}$ of seed cotton processed. Hossam el din (1978), Eweida et al. (1984) found that the feeding rate of seed cotton to gin-stand significantly affected capacity, ginning time and non-lint content. Hughs et al. (1983) found that the total nonlint content of the cotton fiber, most quality factors measured for the cotton lint processed through the experimental gin-cleaner were generally as good if not better than the same quality factors for lint processed through standard cleaning equipment. Anthony (1985) discussed the different features of a ginning machine, the controls and the maintenance which, along with the humidity of the cotton, have an effect in limiting the deterioration of cottonseed and cotton fiber quality (percentage of short fiber and presence of foreign material and seed husk debris). Results 
quoted are from tests at the cotton ginning laboratory. Anthony(1989) reported that processing cotton at the gin to minimize machinery usage and maximize monetary returns requires a thorough understanding of the performance characteristics of individual machines. A database involving multiple moisture, trash, machine and cotton levels was developed for all routine and laboratory fiber properties before and after various gin processes. Ranges of these variables are representative of the min. and max. levels normally found in spindle-harvested cotton. The database is suitable for multiple regression analyses and development of prediction equations based on the performance characteristics of individual and combinations of machines. Rafiq - Chaudhry (1997) found that about $85 \%$ of total cotton in the world is ginned on saw gins. Most countries have either large scale saw ginning or roller ginning, although small scale roller ginning does exist in some countries. Among the major cotton producing countries of the world, India and Turkey are the only countries where saw ginning and roller ginning are popular. Ginning is most expensive in Spain followed by Argentina, Zimbabwe, Australia and Colombia. Ginning is heavily subsidized in China (mainland). Mangialardi and Anthony (2000) found that, cotton (Gossypium hirsutum L.) fibers are cleaned at gins with saw-type lint cleaners to improve the market value, but the aggressive saws sometimes harm the quality of the fiber. The cleaning efficiency of one saw-type lint cleaner averaged 54\%, and the efficiencies of seed cotton cleaners used as lint cleaners ranged from 9 to $16 \%$. There was a significant improvement in the classers' leaf grade designations when lint was cleaned with each of the seed cotton-type cleaners. Staple lengths tended to be shorter after cleaning with saw-type cleaners. A modified non-saw cleaner appears practical and could help preserve fiber quality at cotton gins. Patil et al. (2006 ) found that the foot operated gin and the Lilliput gin have a ginning output capacity of 0.311 and $2.111 \mathrm{~kg} \operatorname{lint} / \mathrm{h}$, respectively. The $2.5 \%$ span length and uniformity ratio remained practically the same for 
hand ginning, foot operated gin and the Lilliput gin. So, the foot operated gin is much more suitable for farmers because it is economical and auxiliary power is not required for its operation. The Lilliput gin is the most popular amongst the cotton breeders, traders and seed industries. Whitelock et al.(2007) stated that most gins use one or two cylinder cleaners and an air-type lint cleaner for lint cleaning. The trend in roller ginning today is toward aggressive seed-cotton cleaning and gentle lint cleaning to limit fiber damage. The aim of present study is to develop and evaluate simple prototype machine to gin Egyptian cotton in laboratory, to help technicians scholars to study the effect of many treatments during operation on fiber cotton quality properties .

\section{MATERIALS AND METHODS}

The gin stand prototype was designed to be used as a ginning system for mechanical harvested seed cotton .So, studying the effect of engineering parameters as rotation drum speeds, feed rates, clearance between two drums, inclination angle of drums with horizontal axis, to estimate the operation optimum conditions, also, to estimate energy requirements and operating cost essential to operation the last overall objective of this work was to test the gin stand developed and compare its performance with the conventional McCarthy gin roller to investigate the machine effects of two different gin stand on physical fiber properties.

A - The gin stand developed: A prototype reciprocating- knife gin having roller length of $70 \mathrm{~cm}$ was fabricated. The adjustment of moving parts of gin stand machine was set according to the conventional settings, which is usually followed with respect to each variety and grad. The power source of the machine is electricity $(0.36 \mathrm{~kW})$. The input power was controlled by a potentiometer to adjust the operating speed. The speeds of different moving parts of the gin stand were fixed and measured by a speedometer. The gin developed machine was fabricated and calibrated in private local workshops at Sofia village, El-Sharkeia 
Governorate. Figure1 shows a schematic diagram of the developed gin stand .The main components of the developed gin machine were as follows:

1- Rolls: its were made from wood covering by natural leather. The gin stand developed was having two rolls used for separated cotton lint from seeds, as, cotton lint are attached in the direction of leather roller, stripping board strip the lint from the leather roller and empty seeds are thrown into grid, through which they pass into suitable receptacle. The dimensions of two rolls have length $700 \mathrm{~mm}$, diameters 150 and $200 \mathrm{~mm}$ respectively and machine weight $65 \mathrm{~kg}$

2-.Moving knife and Stationary knife: the knife serves three purposes

a) It direct (with the roller) seed cotton to the ginning point;

b) It removes seed away from the ginning point; and

c) It removes any seed cotton not able to ginned (carryover).

3- Fly wheel : Made from iron with diameter $380 \mathrm{~mm}$. This diameter is kept on the balanced of machine.

\section{B - The conventional McCarthy gin roller}

The fiber quality parameters of the developed machine were compared with conventional McCarthy gin roller (Figure 2), rotational speed (950 rpm) to evaluate the machine effects. It has the following component parts of

a) Parts for the separation of the fiber from the seed: these include fixed knife, moving knife and roller. These are called the main parts of gin stand.

b) Parts assistance to parts of the separation of the fiber from the seed : they include pusher board, seed grid and doffer.

c) Parts of transmission: these include crank shaft, employment pulley, idler pulley and the transfer of traffic pulleys.

d) Complementary parts like the fund fiber, in addition to the structure gin stand which consists of the thighs. 


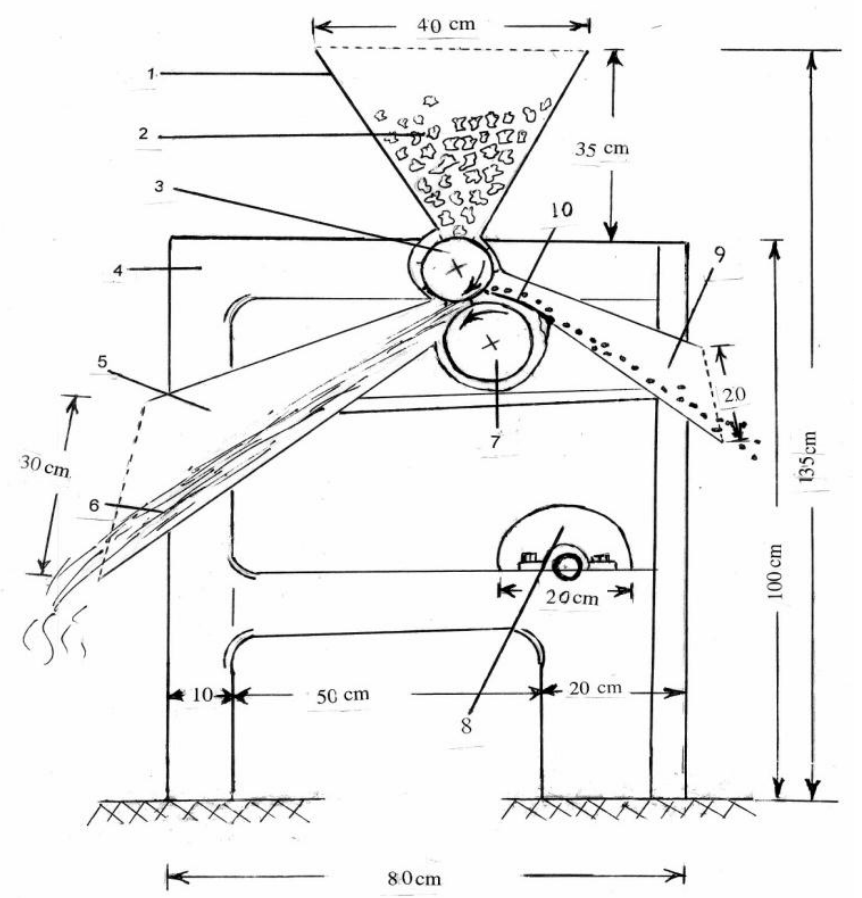

\begin{tabular}{|r|l|}
\hline 1 & Feeding hopper \\
\hline 2 & Raw seed cotton \\
\hline 3 & Doffer \\
\hline 4 & Frame \\
\hline 5 & $\begin{array}{l}\text { Lint output } \\
\text { opening }\end{array}$ \\
\hline 6 & Cotton gin \\
\hline 7 & Ginning roller \\
\hline 8 & Electric motor \\
\hline 9 & $\begin{array}{l}\text { Seed output } \\
\text { opening }\end{array}$ \\
\hline 10 & Seed grid \\
\hline
\end{tabular}

Fig. 1 : cross section of the developed gin stand machine.
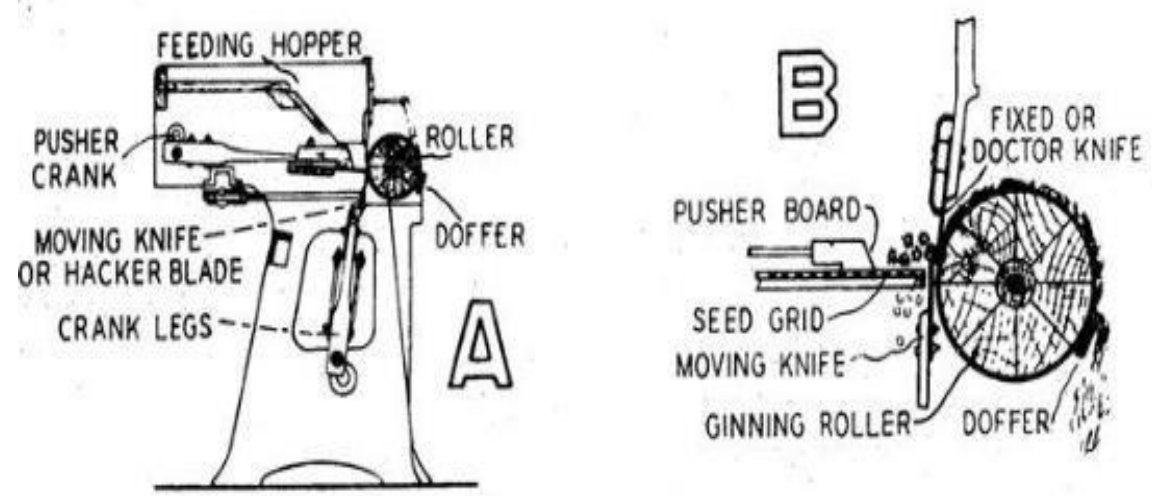

Fig. 2: cross section of the conventional McCarthy gin roller (A) and the main parts of gin stand (B). 


\section{Treatments:}

Four rotation at speeds 0.79 m/s (60 r.p.m), 1.18 m/s (90 r.p.m), 1.60 $\mathrm{m} / \mathrm{s}(120$ r.p.m), and $2.36 \mathrm{~m} / \mathrm{s}(180$ r.p.m). Three feeding rates $30 \mathrm{~kg} / \mathrm{h}, 45$ $\mathrm{kg} / \mathrm{h}$ and $60 \mathrm{~kg} / \mathrm{h}$ and three clearances between two drums 3, 4 and $5 \mathrm{~mm}$ were investigated. The measurements developed machine performance as follows:

\section{1- Machine productivity}

The machine productivity (Q) was calculated by using the following formula:

$\begin{aligned} & \text { Machine } \\ & \text { productivity, } \mathrm{kg} / \mathrm{h}\end{aligned} \quad=\frac{\text { Mass of input seed cotton, } \mathrm{kg}}{\text { The time consummation for ginning, } \mathrm{h} .}$

\section{2- Ginning turn out}

It was determined by using the following formula:

Ginning out turn, $\%=\frac{\text { Lint mass, } \mathrm{kg}}{\text { Seed cotton mass, } \mathrm{kg}}$

\section{3- Gin lint losses}

It was determined by using the following formula:

Jin lint losses, $\mathrm{kg}=$ Weight of seed cotton, $\mathrm{kg}-$ (lint

\section{4- Ginning efficiency}

The percentage of ginning efficiency was determined by using the following formula:

$$
\begin{aligned}
& \text { Ginning } \\
& \text { efficiency, } \%
\end{aligned}=\frac{\begin{array}{l}
\text { Seed cotton mass before ginning, } \mathrm{kg}-\text { seed } \\
\text { wastage mass, } \mathrm{kg}
\end{array}}{\text { Seed cotton mass before ginning, } \mathrm{kg}}
$$

\section{5 - Energy requirement}

The required power was calculated according to the following formula (Gustafson, 1980):

$\begin{gathered}\text { The consumed energy, } \\ (\mathrm{kW} . \mathrm{h} / \mathrm{Mg})\end{gathered} \quad=\frac{\text { Total power consumption }(\mathrm{kW})}{\text { Machine productivity }(\mathrm{Mg} / \mathrm{h}) .(5)}$

Where:-

$$
(\mathrm{kW} . \mathrm{h} / \mathrm{Mg}) \quad \text { Machine productivity }(\mathrm{Mg} / \mathrm{h}) \text {. }
$$

Total required power, $\mathrm{kW}=\sqrt{ }-2 \mathrm{I} \mathrm{V} \operatorname{Cos} \mathrm{\theta} / 1000$

I = Electric current, ampere;

$\mathrm{V} \quad=$ Electric potential, voltage $(220 \mathrm{~V})$;

$\cos \theta=$ Power factor (being equal 0.486)

$\sqrt{-} 2=$ Coefficient current two phases (being equal 1.4) 
While the human energy was calculated as the following equation:

Human energy $=\frac{\text { Manpower, } \mathrm{kW}}{\text { Manual productivity, } \mathrm{Mg} / \mathrm{h}}$

The manpower was computed by assuming that one normal labor supplies $0.0748 \mathrm{~kW}$ according to (Ezekiel, 1987) cited by (Matouk et al.1999)

\section{6 - Operational cost of the unit}

The total cost was determined by using the following equation (Awady,1978)

$\mathrm{C}=\mathrm{p} / \mathrm{h}(1 / \mathrm{a}+\mathrm{i}+\mathrm{t} / 2+\mathrm{r})+(\mathrm{Ec} \times \mathrm{Ep})+\mathrm{m} / 144$

$\mathrm{C}=$ Operation hourly cost, L.E/h. $\quad \mathrm{p}=$ Price of machine, L.E.

$\mathrm{h}=$ Yearly working hours, h/year $\quad \mathrm{Ep}=$ Electricity price, $(\mathrm{EL} / \mathrm{kW} . \mathrm{h})$

$\mathrm{Ec}=$ Electricity energy consumption $\mathrm{r}=$ Overheads and indirect cost ,$(\mathrm{kW} / \mathrm{h})$ ratio

$\mathrm{a}=$ Life expectancy of the machine, $\mathrm{h} \quad \mathrm{m}=$ Monthly average wage, L.E.

$\mathrm{i}=$ Interest rate/year. $\mathrm{t}=$ Taxes ratio

$144=$ The estimated monthly working hours, $\mathrm{h} / \mathrm{mon}$

Where:

Also, Unit operating $\cos t, L E / M g=\frac{\operatorname{Pr} \text { ototype } \cos t(L E / h)}{\operatorname{Pr} \text { oductivity }(M g / h)} \ldots \ldots \ldots . . .(9)$

Criterion function cost, $\mathrm{LE} / \mathrm{Mg}=$ unit operating cost, $\mathrm{LE} / \mathrm{Mg}+$ Losses

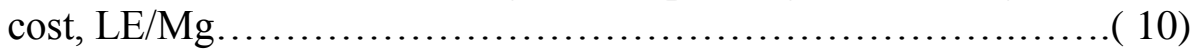

Losses cost, $\mathrm{LE} / \mathrm{Mg}=$ value of lint wastage + fewness in cotton seed price according to reducing seed damaged.

\section{7 - The fiber quality properties}

The fiber properties were determined at fiber testing laboratory, CRI, ARC, Giza. As follows:

A - Fiber length: The digital fibrograph model 630 used to determine 2.5 and $5 \%$ span fiber length according to May and Bridges, (1995).

B - Uniformity ratio: Determined by using the following formula: while it was had $2 \mathrm{~cm}$ round holes diameter with saw drums concaves $50 \%$ span fiber length

Uniformity ratio, $\%=\frac{}{2.5 \% \text { span fiber length }}$ $\times 100$

Where, it was expressed on uniformity quantity between short and long fiber length. 
C -Lint Color: HVI 9000 according to ASTM (D-1684-96) estimated lint color (reflectance $\mathrm{Rd}, \%$ and yellowness $+\mathrm{b}$ )

D - Fibers strength and elongation: Measured by using stelometer instrument at fiber testing laboratory, CRI, ARC according to (ASTM, designated D-1445-75, 1984). Where, this instrument give elongation reading and cotton strength can be determined by using the following formula: $\begin{aligned} & \text { Strength for } \\ & \text { length unit, } g / \text { tex }\end{aligned}=\frac{\text { cutting mass, } \mathrm{kg} \times 1.5 \times}{\text { mass of sample, } \mathrm{mlg}} 100$

\section{RESULTS AND DISCUSSION}

\section{A- Primordial Test :}

Primary experiment was carried out during season 2009 at ginning seed cotton variety Giza 89 with using the conventional McCarthy gin roller, to determine the effect of some independent variables such as drum speed, feeding rate and clearance between drums on gin stand performance.Table1 show the average the conventional McCarthy gin roller processing data. This study proved that this machine is not suitable for low feed rates and therefore they do not fit the research tests urged it was designed for production only. Therefore there are been a urgent need of a model of ginning machines suitable for research experiments and for this reason has been the subject of machine design of the present study.

Table1: Average the conventional McCarthy gin roller processing data.

\begin{tabular}{|l|c|}
\hline \multicolumn{1}{|c|}{ Factor } & Amount \\
\hline Lint system ginning efficiency , \% & 73.8 \\
\hline Gin turn out , \% & 28.6 \\
\hline Lint loss , \% & 4.6 \\
\hline Ginning rate , kg / saw / h & 10.4 \\
\hline
\end{tabular}

\section{B - Performance of development gin stand machine :}

\section{1- Gin stand productivity, $\mathrm{kg} / \mathrm{h}$ :}

Fig 3 show average gin processing for seed cotton variety Giza 89 usage development gin stand machine. Data illustrate that gin stand productivity was affected by drum speed, feeding rate and clearance 
between drums. It's clear that gin stand productivity was increased by increasing all of drum speed, feeding rate and clearance between drums. whereas, at constant feed rate and clearance between drums at $30 \mathrm{~kg} / \mathrm{h}$ and $3 \mathrm{~mm}$ and increase drum speed from $0.79 \mathrm{~m} / \mathrm{s}$ to $2.36 \mathrm{~m} / \mathrm{s}$, gin stand productivity increased from $15.57 \mathrm{~kg} / \mathrm{h}$ to $16.12 \mathrm{~kg} / \mathrm{h}(+3.53 \%)$. While, with increasing feeding rate from $30 \mathrm{~kg} / \mathrm{h}$ to $60 \mathrm{~kg} / \mathrm{h}$ at constancy drum speed and clearance between drums at $0.79 \mathrm{~m} / \mathrm{s}$ and $3 \mathrm{~mm}$ respectively, gin stand productivity increased from $15.57 \mathrm{~kg} / \mathrm{h}$ to $29.9 \mathrm{~kg} / \mathrm{h}(+92 \%)$. Also, at increasing clearance between drums from $3 \mathrm{~mm}$ to $5 \mathrm{~mm}$ at constant drum speed and feed rate at $30 \mathrm{~kg} / \mathrm{h}$ and $0.79 \mathrm{~m} / \mathrm{s}$, gin stand productivity increased from $15.57 \mathrm{~kg} / \mathrm{h}$ to $15.71 \mathrm{~kg} / \mathrm{h}(+0.89 \%)$. From previous results, feeding ate consider as very important factor affected on gin stand productivity. On the other hand, a maximum of gin stands productivity was $32.8 \mathrm{~kg} / \mathrm{h}$ recorded at drum speed of $2.36 \mathrm{~m} / \mathrm{s}$, feeding rate of $60 \mathrm{~kg} / \mathrm{h}$ and clearance between drums of $5 \mathrm{~mm}$.

\section{2- lint turn out ,\% :}

From Fig. 4 results indicates that, increasing drum speed and clearance between drums led to increase lint turn out, while increasing feeding rate led to decease lint turn out . Whereas, at used constant feeding rate and clearance between drums at $30 \mathrm{~kg} / \mathrm{h}$ and $3 \mathrm{~mm}$ with increasing drum speed from $0.79 \mathrm{~m} / \mathrm{s}$ to $2.36 \mathrm{~m} / \mathrm{s}$, lint turn out increased from $38.8 \%$ to $41.4 \%(+6.7 \%)$. On the contrary, at used feeding rate and drum speed of $30 \mathrm{~kg} / \mathrm{h}$ and $0.79 \mathrm{~m} / \mathrm{s}$, lint turn out increased from $38.8 \%$ to $40.3 \%$ $(+3.86 \%)$. While, at used drum speed of $0.79 \mathrm{~m} / \mathrm{s}$ and clearance between drums of $3 \mathrm{~mm}$ and by increasing feeding rate from $30 \mathrm{~kg} / \mathrm{h}$ to $60 \mathrm{~kg} / \mathrm{h}$, lint turn out decreased from $39.4 \%$ to $38.3 \%(-2.8 \%)$. The maximum value of lint turn out was $43.1 \%$ recorded at drum speed of $2.36 \mathrm{~m} / \mathrm{s}$, feeding rate of $30 \mathrm{~kg} / \mathrm{h}$ and clearance between drums of $5 \mathrm{~mm}$.

\section{3- Seed wastage mass, $\mathrm{kg}$ :}

Fig.5 indicated that, seed wastage mass tend to decrease with increasing all of drum speed and clearance between drums. While, it was increase with increasing feeding rate. On the whole results recorded a maximum amount of seed wastage mass was $17.49 \mathrm{~kg}$ at using feeding rate of 60 $\mathrm{kg} / \mathrm{h}$, drum speed of $0.79 \mathrm{~m} / \mathrm{s}$ and clearance between drums of $3 \mathrm{~mm}$. It's clear that, at using feeding rate of $30 \mathrm{~kg} / \mathrm{h}$, clearance between drums of 3 $\mathrm{mm}$ and increase drum speed from $0.79 \mathrm{~m} / \mathrm{s}$ to $2.36 \mathrm{~m} / \mathrm{s}$, seed wastage mass decrease from $8.21 \mathrm{~kg}$ 

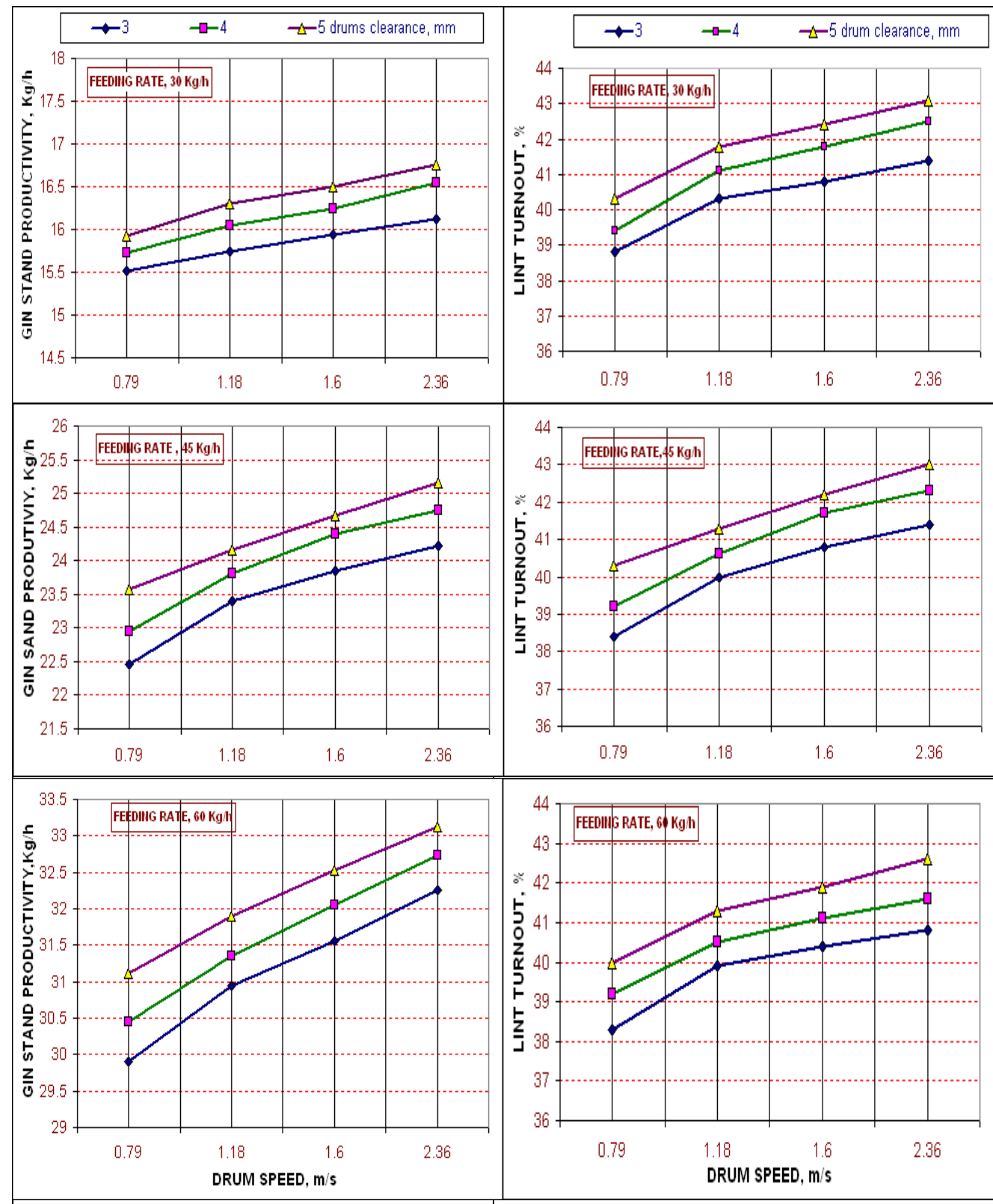

Fig 3 : Effect of drum speed, feed rate and clearance between two drums on gin stand productivity ,

Fig 4 : Effect of drum speed, feed rate and clearance between two $\mathrm{kg} / \mathrm{h}$. drums on lint turn out, $\%$. 
to $7.81 \mathrm{~kg}(-4.87 \%)$. Also, at using drum speed of $0.79 \mathrm{~m} / \mathrm{s}$, clearance between drums of $3 \mathrm{~mm}$ and increasing feeding rate from $30 \mathrm{~kg} / \mathrm{h}$ to 60 $\mathrm{kg} / \mathrm{h}$. seed wastage mass increase from $8.21 \mathrm{~kg}$ to $17.49 \mathrm{~kg}(+113 \%)$ seed wastage mass decrease too from $8.21 \mathrm{~kg}$ to $7.76 \mathrm{~kg} \mathrm{(-5.48 \% )}$ at using feeding rate of $30 \mathrm{~kg} / \mathrm{h}$, drum speed of $0.79 \mathrm{~m} / \mathrm{s}$ and increase clearance between drums from $3 \mathrm{~mm}$ to $5 \mathrm{~mm}$.

\section{4- Energy requirement, $\mathrm{kW} . \mathrm{h} / \mathrm{Mg}$ :}

Data presented in Fig. 6 show the effect of drum speed, feed rate and clearance between drums on energy requirements. It's observed that, increasing drum speed from $0.79 \mathrm{~m} / \mathrm{s}$ to $2.36 \mathrm{~m} / \mathrm{s}$ tends to increase energy requirements. While, increasing feed rate from $30 \mathrm{~kg} / \mathrm{h}$ to $60 \mathrm{~kg} / \mathrm{h}$ or increasing clearance between drums from $3 \mathrm{~mm}$ to $5 \mathrm{~mm}$ led to decrease energy requirements. As it was to allow the passage of the samples easily without making contact with a large capacity, less the rate of energy required. A minimum energy requirements was $154.26 \mathrm{~kW} . \mathrm{h} / \mathrm{Mg}$ recorded at using drum speed of $0.79 \mathrm{~m} / \mathrm{s}$, feed rate of $60 \mathrm{~kg} / \mathrm{h}$ and clearance between drums of $5 \mathrm{~mm}$.

\section{5- Ginning efficiency and gin lint losses percentage}

Ginning efficiency and gin lint losses percentage as related to the drum speed, feeding rate and clearance between drums are shown in Fig. 7. It's clear that, increasing drum speed, feed rate and clearance between drums led to decrease ginning efficiency at all experimental points. Also, increasing drum speed and clearance between drums led to increasing gin lint losses percentage while, increasing feeding rate led to decrease gin lint losses percentage. And through the intersection curves of ginning efficiency and estimate the proportion of lint losses can determine the optimum conditions for operating the machine, which then will be suitable efficiency with less ginning percentage or an acceptable degree of lint losses. And through the signing of curves graphically possible to identify optimum conditions for operating the machine manufacturer when drum speed and feeding rate and clearance between the drums. Accordingly the optimum operating conditions for the gin stand developed was recorded at drum speed of $0.79 \mathrm{~m} / \mathrm{s}$, feed rate of $45 \mathrm{~kg} / \mathrm{h}$ and clearance between drums of $3 \mathrm{~mm}$. Where it was produced high value of ginning efficiency equal $80.69 \%$ and low value of gin lint losses percentage equal $5.19 \%$, respectively. 


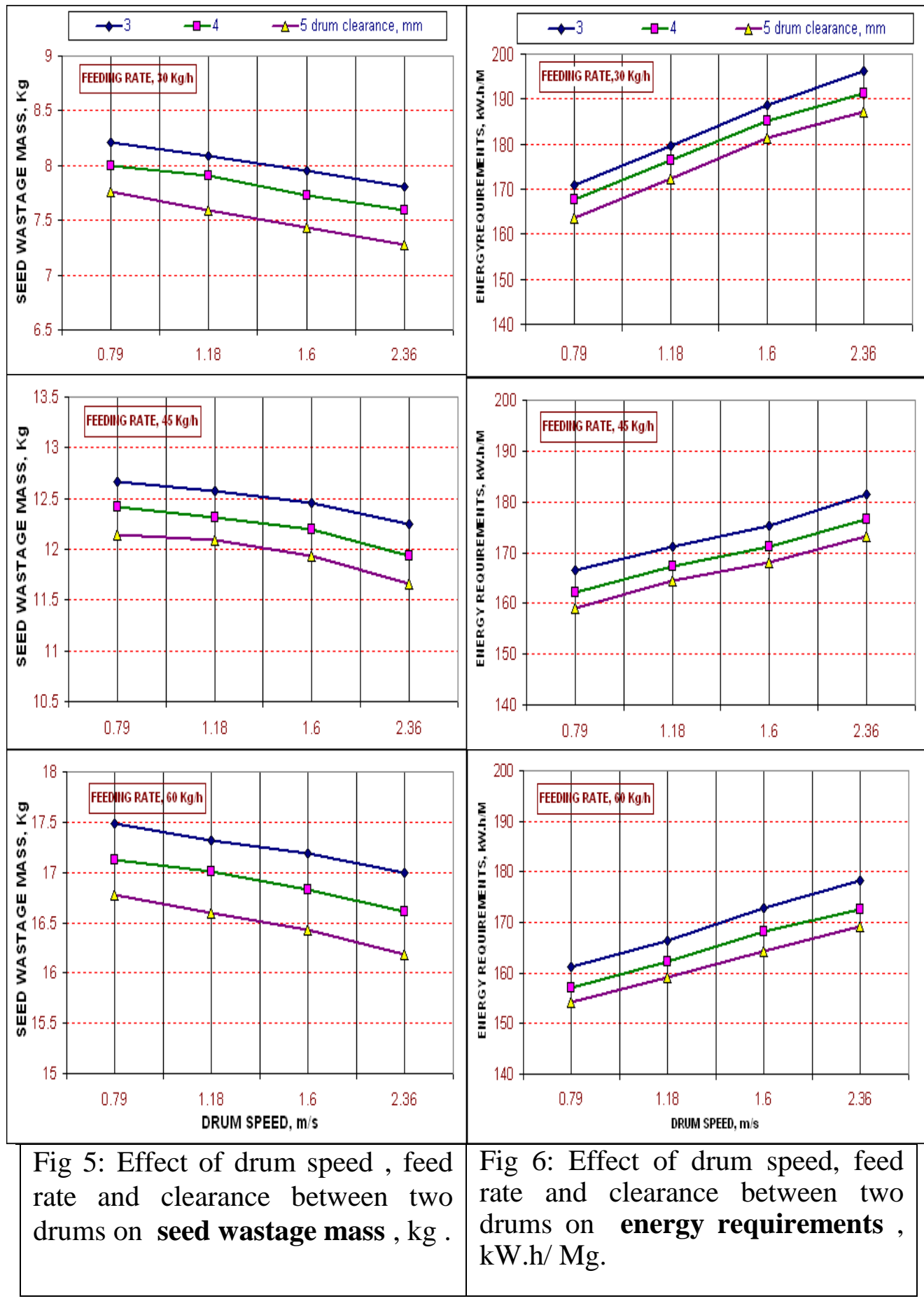




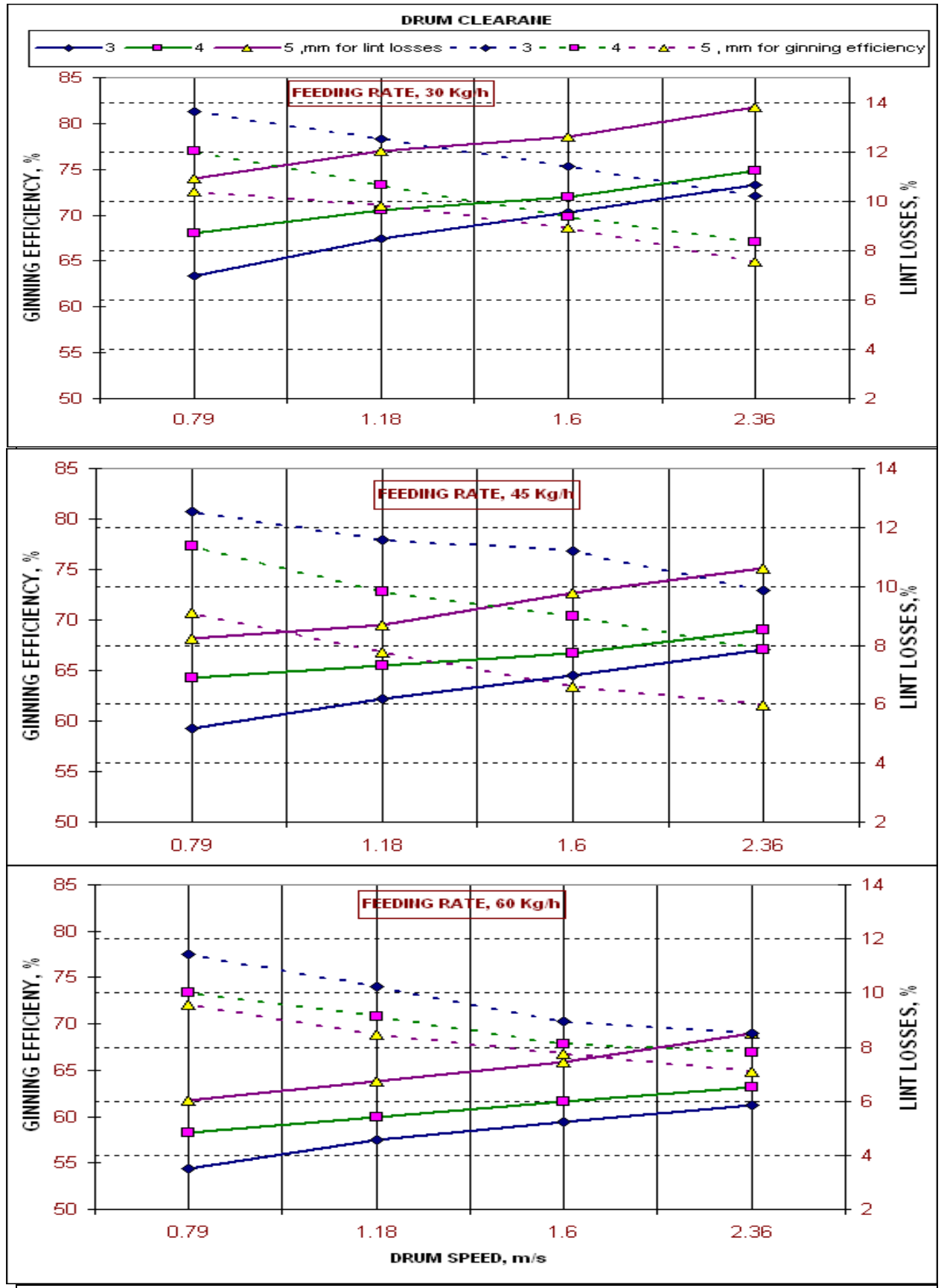

Fig.7: The relation between drum speed and both of ginning efficiency and gin lint losses ,\% at different feed rates and drum clearances. 


\section{6- Total production cost and criterion function determination :}

Table 2 illustrates the effect of drum speed on total production cost and criterion function cost at different levels of feeding rate and clearance between two drums. whereas, the total production cost was decreased with increasing drum speed, increasing feeding rate and with increasing clearance between two drums. Vice versa, criterion function was increased at the same previous conditions. On the other hand, criterion function cost was estimated by total cost of all of the operating costs and machine costs in the lint losses and machine costs in the seed damaged. In addition to, a minimum total cost production was $231.40 \mathrm{~L} . \mathrm{E} / \mathrm{Mg}$ recorded at drum speed of $2.36 \mathrm{~m} / \mathrm{s}$, feeding rate of $60 \mathrm{~kg} / \mathrm{h}$ and clearance between two drums of $5 \mathrm{~mm}$. while, a minimum criterion function cost was $364.10 \mathrm{LE} / \mathrm{Mg}$ recorded at drum speed of $0.79 \mathrm{~m} / \mathrm{s}$, feeding rate of $60 \mathrm{~kg} / \mathrm{h}$ and clearance between two drums of $3 \mathrm{~mm}$ respectively.

Table 2 : Total production cost and criterion function cost for the gin stand developed

\begin{tabular}{|c|c|c|c|c|c|c|c|}
\hline \multirow{2}{*}{$\begin{array}{l}\text { Feed } \\
\text { rate, } \\
\mathrm{Kg} / \mathrm{h}\end{array}$} & \multirow{2}{*}{$\begin{array}{r}\begin{array}{r}\text { Clearance } \\
\text { between } \\
\text { drums, } \\
\text { mm } \\
\text { Drum }\end{array} \\
\text { speed } \\
\text {,m/s }\end{array}$} & \multicolumn{3}{|c|}{$\begin{array}{l}\text { Total production cost, } \\
\text { L.E/Mg }\end{array}$} & \multicolumn{3}{|c|}{$\begin{array}{c}\text { Criterion Function Cost, } \\
\text { LE/Mg }\end{array}$} \\
\hline & & $3 \mathrm{~mm}$ & $4 \mathrm{~mm}$ & $5 \mathrm{~mm}$ & $3 \mathrm{~mm}$ & $4 \mathrm{~mm}$ & $5 \mathrm{~mm}$ \\
\hline \multirow[t]{4}{*}{30} & 0.79 & 388.74 & 384.06 & 379.5 & 599.12 & 660.84 & 722.42 \\
\hline & 1.18 & 378.57 & 371.5 & 365.5 & 657.75 & 671.80 & 757.80 \\
\hline & 1.60 & 374.10 & 367.2 & 361.36 & 683.55 & 688.27 & 776.21 \\
\hline & 2.36 & 369.76 & 360.6 & 355.70 & 699.46 & 722.97 & 818.57 \\
\hline \multirow[t]{4}{*}{45} & 0.79 & 318.64 & 311.76 & 303.40 & 466.97 & 482.53 & 554.40 \\
\hline & 1.18 & 305.77 & 300.60 & 285.20 & 511.82 & 509.11 & 555.00 \\
\hline & 1.60 & 300.00 & 293.30 & 251.98 & 520.77 & 523.20 & 562.28 \\
\hline & 2.36 & 295.50 & 289.00 & 234.40 & 538.83 & 543.90 & 577.63 \\
\hline \multirow[t]{4}{*}{60} & 0.79 & 265.80 & 261.00 & 251.90 & 364.10 & 399.56 & 433.76 \\
\hline & 1.18 & 255.20 & 251.18 & 246.50 & 398.62 & 404.99 & 451.68 \\
\hline & 1.60 & 251.90 & 248.00 & 243.50 & 419.50 & 414.78 & 466.95 \\
\hline & 2.36 & 246.50 & 242.30 & 231.40 & 417.66 & 437.45 & 494.80 \\
\hline
\end{tabular}




\section{C- Effect of Gin Machine Type on The fiber quality parameters:}

Table 3 illustrates the properties for fiber quality which produced by the gin stand developed and the conventional McCarthy gin roller at optimum operation condition. Results show that, developed gin stand was give good outcome compared with the conventional McCarthy gin roller. Where it was recorded high value of span fiber length $2.5 \%(\mathrm{~mm})$, span fiber length $50 \%(\mathrm{~mm})$, uniformity ratio $(\%)$, fiber reflectance $(\%)$ and fiber strength $(\mathrm{g} / \mathrm{tex})$. While, the conventional McCarthy gin roller was recorded high value of fiber yellowness (unit) and fiber elongation (\%).

Table 3: The fiber quality parameters at optimum operation conditions.

\begin{tabular}{|l|c|c|}
\hline \multicolumn{1}{|c|}{$\begin{array}{c}\text { Ginning stand } \\
\text { machines } \\
\text { Fiber quality }\end{array}$} & $\begin{array}{c}\text { The gin stand } \\
\text { developed }\end{array}$ & $\begin{array}{c}\text { McCarthy gin } \\
\text { roller }\end{array}$ \\
\hline Span fiber length $\mathbf{2 . 5} \%, \mathbf{m m}$ & 31.1 & 30.8 \\
\hline Span fiber length 50\%,mm & 14.8 & 14.1 \\
\hline Uniformity ratio, $\%$ & 47.6 & 45.8 \\
\hline Fiber reflectance, \% & 68.0 & 66.4 \\
\hline Fiber yellowness, unit & 6.1 & 6.5 \\
\hline Fiber strength ,g/tex & 29.1 & 28.0 \\
\hline Fiber elongation, $\%$ & 6.9 & 7.3 \\
\hline
\end{tabular}

So, the gin stand developed was consider the best for ginning Egyptian seed cotton samples.

\section{CONCLUSION}

The research can be concluded that :

1- At determination the developed gin stand capacity, it was agreed directly relation with increasing drum speed, feed rate and clearance between drums. Also, the maximum capacity was $32.8 \mathrm{~kg} / \mathrm{h}$ recorded at using drum speed of $2.36 \mathrm{~m} / \mathrm{s}$, feed rate of $60 \mathrm{~kg} / \mathrm{h}$ and clearance between drums of $5 \mathrm{~mm}$.

2-Lint turn out percentage was agreed directly relation with increasing 
drum speed and increasing clearance between drums, maximum lint turn out was $43.1 \%$ recorded at using drum speed of $2.36 \mathrm{~m} / \mathrm{s}$, feed rate of $30 \mathrm{~kg} / \mathrm{h}$ and clearance between drums of $5 \mathrm{~mm}$.

3- Seeds wastage mass was had directly relation with all independent variables. Also, the maximum seeds wastage mass was $17.49 \mathrm{~kg}$ recorded at using drum speed of $0.79 \mathrm{~m} / \mathrm{s}$, feed rate of $60 \mathrm{~kg} / \mathrm{h}$ and clearance between drums of $5 \mathrm{~mm}$. On other hand, gin lint losses percentage was had directly relation with drum speed and clearance between drums while, it was had reversely relation with feed rate Whereas, the minimum value was $3.5 \%$ recorded at using drum speed of $0.79 \mathrm{~m} / \mathrm{s}$, feed rate of $60 \mathrm{~kg} / \mathrm{h}$ and clearance of $3 \mathrm{~mm}$.

4- Developed gin stand machine was had maximum ginning efficiency equal $81.28 \%$ at using drum speed of $0.79 \mathrm{~m} / \mathrm{s}$, feed rate of $30 \mathrm{~kg} / \mathrm{h}$ and clearance of $3 \mathrm{~mm}$.

5- Minimum value of energy requirements was $154.26 \mathrm{~kW} . \mathrm{h} / \mathrm{Mg}$ at using drum speed of $0.79 \mathrm{~m} / \mathrm{s}$, feed rate of $60 \mathrm{~kg} / \mathrm{h}$ and clearance of $5 \mathrm{~mm}$.

6-Minimum value of total production cost was $231.40 \mathrm{~L} . \mathrm{E} / \mathrm{Mg}$ recorded at using drum speed of $2.36 \mathrm{~m} / \mathrm{s}$, feed rate of $60 \mathrm{~kg} / \mathrm{h}$ and clearance of $5 \mathrm{~mm}$. While, minimum of criterion function cost $364.10 \mathrm{LE} / \mathrm{Mg}$ was recorded at using drum speed of $0.79 \mathrm{~m} / \mathrm{s}$, feed rate of $60 \mathrm{~kg} / \mathrm{h}$ and clearance of $3 \mathrm{~mm}$

7- A comparison study between effects of the gin stand developed and McCarthy gin roller on fiber quality parameters, it illustrate that, the gin stand developed was consider the best for ginning Egyptian seed cotton samples.

\section{REFERENCES}

ASTM,Standards(1982). Designatians:64,(884-96)ASTM, Philadelphia ,Pa, USA..

ASTM, Standards (1984). Designations: 1445 - 75. American society for testing and materials. Standards of textile testing and materials .The society, philadelaphia, USA. 
Awady,M.N.1978. Tractors and farm machine, in Arabic, text. Col. Ag., Ain Shams Univ.; 164-167.

Anthony, W.S.1979. Energy-quality considerations in modeling cotton ginning systems. Trans. of The ASAE. 22(3): 644-648.

Anthony, W.S.1985. Effect of gin stands on cotton fiber and seed Cotton. Gin and Oil Mill Press.; 86(16): 14-18.

Anthony, W.S.1989. Performance characteristics of cotton ginning machinery . American Society of Agricultural Engineers.; Paper (89-1010): $26 \mathrm{pp}$.

Eweida, M.A.; G.A.Morshedi; M.A, Risk and S.S.Marzook (1984). Effect of the rotary knife gin -stand adjustment and cleaning the cotton lint on ginning efficiency in some Egyptian and upland cotton varieties. Agric.res.rev. 62(6): $301-311$.

Ezeike, M.S. 1987. Energy requirements for cotton gin machinery. Applied Engineering in Agriculture. 12(3): 455-473.

Gustafson, R.J. 1980. Fundamentals of Electricity for Agriculture. The AVI publishing company, Inc. Westport, Connecticut.

Hossam el-din, A.E. (1978) Ginning efficiency as affected by cotton characteristics and some other major factors. Ph.D thesis. Fac. of Agric. Al -azhar Univ.

Hughs, S.E.; M.N. Gillum and W.F. Lalor.1983 Fiber quality from a combination gin-lint cleaner. American Society of Agricultural Engineers. Paper No. ( 83-3533): 15 pp.

Matouk A. M. ; Y. M. El-Hadidi and H. El-Mashad.1999. Energy accounting and management in some food plants. Misr Journal of Agric. Eng. 16 (1) : 157-175.

Mangialardi, G.J. and W.S. Anthony 2000. Engineering and ginning: feasibility of applying seed cotton cleaning principles to lint cleaning. Journal of Cotton Science. 4(3): 183-192.

May, O.L.and B.C. Bridges, Tr. (1995). Breeding cottons for conventional and late planted production systems. Crop Sci. 35: 132-136. 
Patil, P.G.;S.K. Shukla and V.G. Arude 2006. Design development and performance evaluation of portable cotton ginning machines. AMA, 37(1): 30-34.

Rafiq-Chaudhry, M. 1997. Harvesting and ginning of cotton in the world. Proceedings Beltwide Cotton Conferences, New Orleans, LA, USA, Volume 2 : 1617-1619.

\section{Whitelock, D.P; C.B. Armijo; G.R.Gamble and S.E. Hughs 2007.} Survey of seed-cotton and lint cleaning equipment in U.S. roller gins. USDA - ARS Southwestern Cotton Ginning Research Lab, 300 E College Journal of Cotton Science. 11(3): 128-140.

$$
\begin{aligned}
& \text { الملخص العربي } \\
& \text { تطوير نموذج أولى لحلاجة بسيطة تناسب القطن المصري. } \\
& \text { شرين فؤاد عبد الحميد* ـ عاطف عزت اليماني*_ سامي السعيد بلرر }
\end{aligned}
$$

محصول القطن من المحاصيل الهامـة التي ظلت مؤثرة على الاقتصـاد القومي المصري لفترة

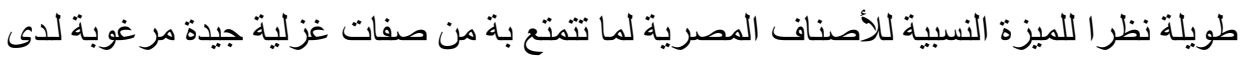

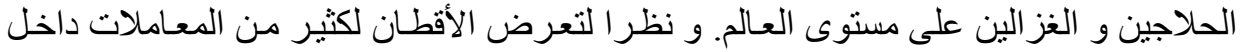

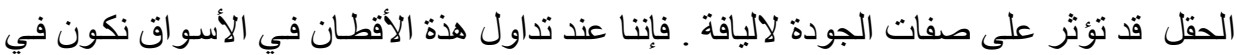

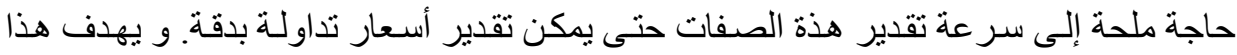

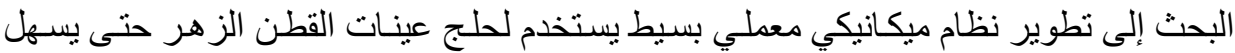

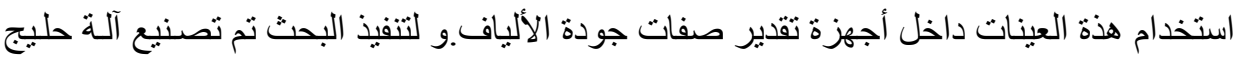

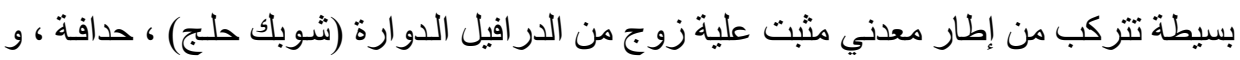

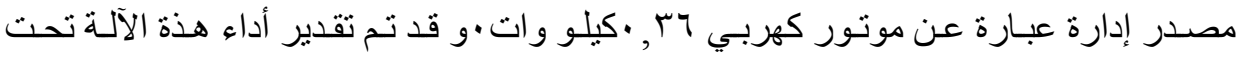

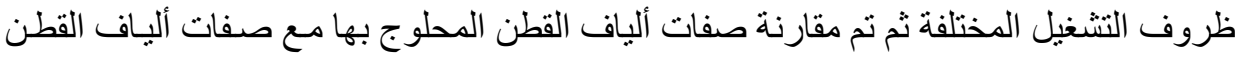

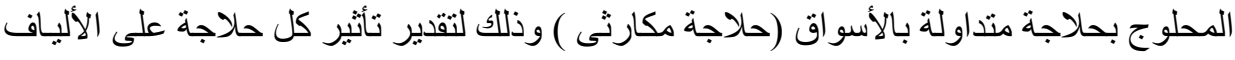

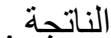

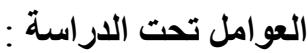

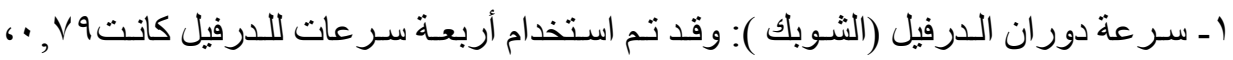
.

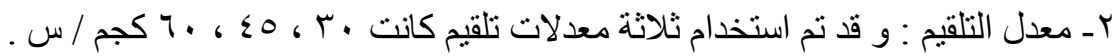

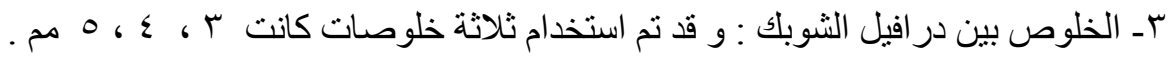

*قسم ميكنة المحاصيل الحقلية والبستانية - معهد بحوث الهندسة الزراعيةـ الدقى ـالجيزة ـ مصر 
- و قد تم تقييم أداء الحلاجة المطورة من خلال دراسة مؤشرات الكفاءة التالية :

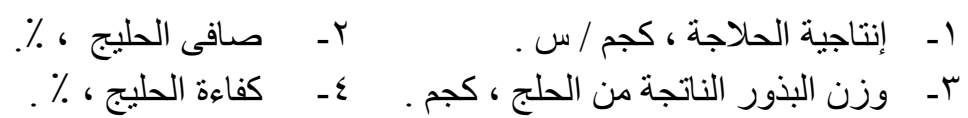

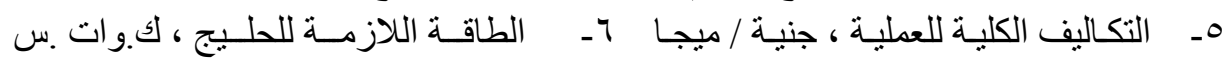

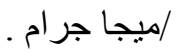

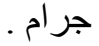

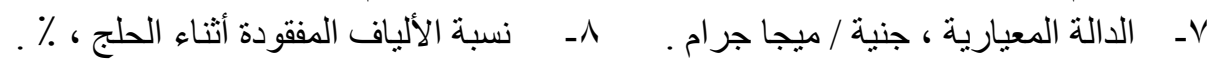
و أيضا تم تقدير صفات جودة ألياف القطن التالية لكلتا الحلاجنين :

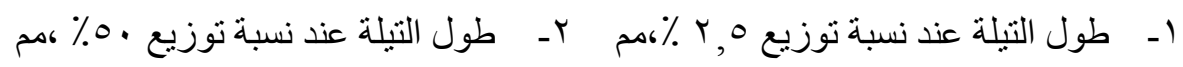

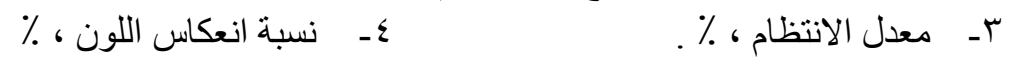

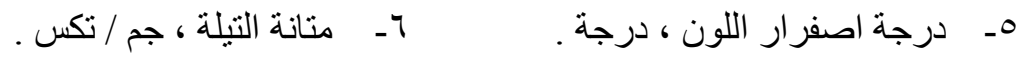

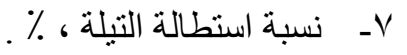

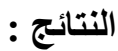

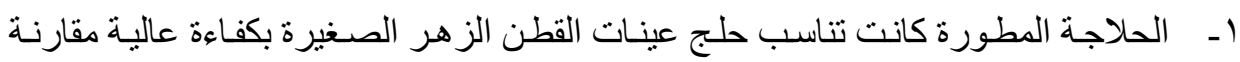

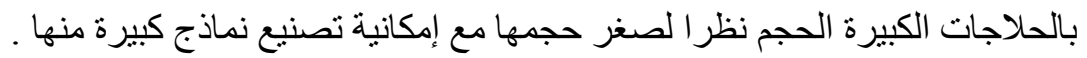

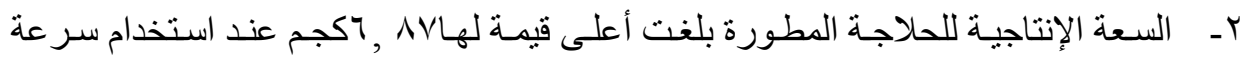

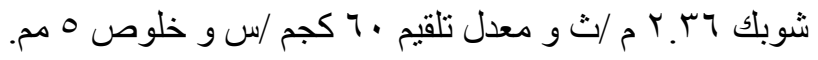

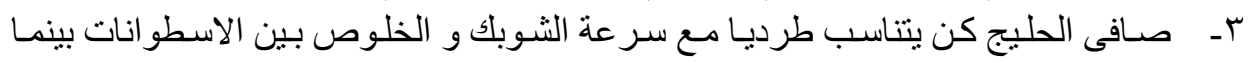

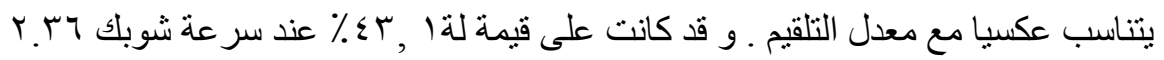

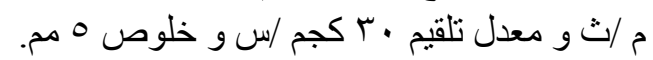

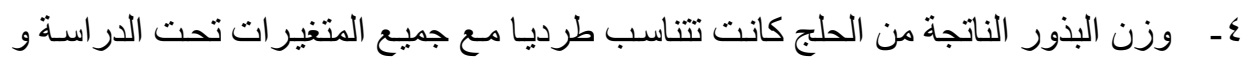

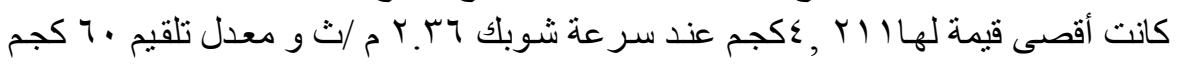

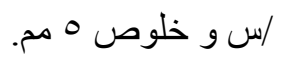
هـ نسبة الألياف المفقودة أثناء الحلج كانت تزداد مـع زيـادة سر عة الثوبك و زيادة الخلوص بينما تقل مع زيادة معدل التلقيم

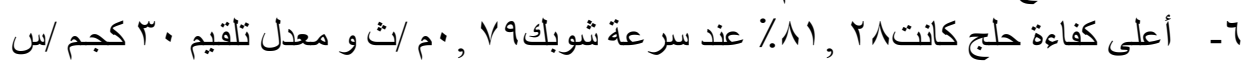

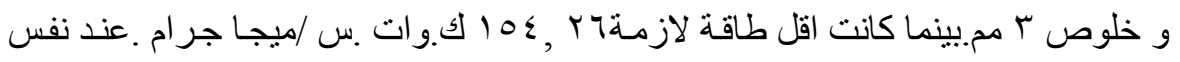

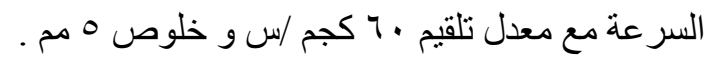

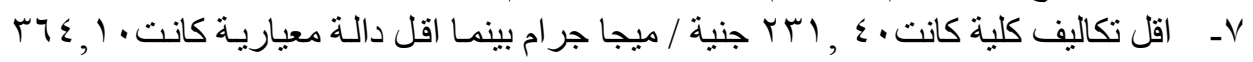

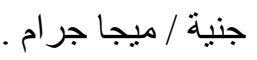
1- بمقارنـة صفات جودة الألياف وجد أن الآلة المطورة كانت تحافظ على الصفات بدرجة أعلى من حلاجة مكارثى التقليدية. 